\title{
Effects of precipitation on soil acid phosphatase activity in three successional forests in southern China
}

\author{
W. Huang ${ }^{1,2}$, J. Liu ${ }^{1}$, G. Zhou ${ }^{1}$, D. Zhang ${ }^{1}$, and Q. Deng ${ }^{1,2}$ \\ ${ }^{1}$ South China Botanical Garden, Chinese Academy of Sciences, Guangzhou 510650, China \\ ${ }^{2}$ Graduate University of the Chinese Academy of Sciences, Beijing 100049, China
}

Received: 24 July 2010 - Published in Biogeosciences Discuss.: 7 January 2011

Revised: 11 July 2011 - Accepted: 13 July 2011 - Published: 18 July 2011

\begin{abstract}
Phosphorus (P) is often a limiting nutrient for plant growth in tropical and subtropical forests. Global climate change has led to alterations in precipitation in the recent years, which inevitably influences $P$ cycling. Soil acid phosphatase plays a vital role in controlling $\mathrm{P}$ mineralization, and its activity reflects the capacity of organic $\mathrm{P}$ mineralization potential in soils. In order to study the effects of precipitation on soil acid phosphatase activity, an experiment with precipitation treatments (no precipitation, natural precipitation and doubled precipitation) in three successional forests in southern China was carried out. The three forests include Masson pine forest (MPF), coniferous and broadleaved mixed forest (MF) and monsoon evergreen broadleaved forest (MEBF). Results showed that driven by seasonality of precipitation, changes in soil acid phosphatase activities coincided with the seasonal climate pattern, with significantly higher values in the wet season than in the dry season. Soil acid phosphatase activities were closely linked to forest successional stages, with enhanced values in the later stages of forest succession. In the dry season, soil acid phosphatase activities in the three forests showed a rising trend with increasing precipitation treatments. In the wet season, soil acid phosphatase activity was depressed by no precipitation treatment in the three forests. However, doubled precipitation treatment exerted a significantly negative effect on it only in MEBF. These results indicate that the potential transformation rate of organic $\mathrm{P}$ might be more dependent on water in the dry season than in the wet season. A decrease in organic $P$ turnover would occur in the three forests if there was a drought in a whole year in the future. More rainfall in the wet season would also be adverse to organic $\mathrm{P}$ turnover in MEBF due to its high soil moisture.
\end{abstract}

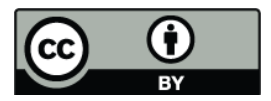

Correspondence to: $\mathrm{G}$. Zhou (gyzhou@scib.ac.cn)

\section{Introduction}

Phosphorus $(\mathrm{P})$ limitation to forest primary productivity and other ecosystem processes is widespread in tropical forests (Attiwill and Adams, 1993). Most soil P is bound in detritus as organic $\mathrm{P}$ and remains inaccessible to plants. Apart from the weathering of parent material in soils, $\mathrm{P}$ input depends on the mineralization of soil organic matter. Phosphatases, originating from fungi, bacteria and root exudates, catalyze the hydrolysis of ester bonds between phosphate and carbon compounds in organic substrates to enhance $P$ availability to ecosystems (Turner and Haygarth, 2005). The production of phosphatase would be increased when the requirement for P by forest ecosystems is increased (Clarholm, 1993; Olander and Vitousek, 2000). These enzymes therefore play an important role in maintaining and controlling the rate of $\mathrm{P}$ cycling in forest ecosystems. Of the phosphatases, acid phosphatase is predominant in forest soils due to their pH optima (Juma and Tabatabai, 1988). Its activity can provide useful information on organic $\mathrm{P}$ mineralization potential and biological activity of soils (Speir and Ross, 1978; Dick and Tabatabai, 1993; Krämer and Green, 2000). Acid phosphatase activity has been used as an indicator in several studies to evaluate P limitation in forest ecosystems (Schneider et al., 2001; Gress et al., 2007).

Changes to global precipitation (Houghton et al., 2001) have potential to greatly influence $\mathrm{P}$ cycling dynamics, since soil moisture is a key factor of controlling $\mathrm{P}$ availability in soils through several processes, including affecting mineralization processes, influencing $\mathrm{P}$ demand for plant growth and impacting microbial activity (Leiros et al., 1999; Raghothama, 1999; Grierson and Adams, 2000; Sardans et al., 2007). In some increased drought areas, such as the Mediterranean, dry conditions lead to a great degree of $\mathrm{P}$ limitation to plant growth because of a decrease in $\mathrm{P}$ supply through impairing soil phosphatase activity (Garcia et

Published by Copernicus Publications on behalf of the European Geosciences Union. 
al., 2002; Sardans and Penuelas, 2005). During the latter part of the 20th century, there has been a decreasing trend in precipitation over northern China, while a significant increase in precipitation was also detected over the middle and lower reaches of the Yangtze River and west China (Zhai et al., 1999). Our study also showed that the monthly precipitation in northern Guangdong province had changed a lot in the past decades (Luo et al., 2008). Changes in precipitation are, therefore, likely to affect the rate of $\mathrm{P}$ turnover and soil $\mathrm{P}$ availability. Soil acid phosphatase associating with $\mathrm{P}$ cycling in forest ecosystems is an exceptional entry point for accessing the effects of variations in precipitation on $\mathrm{P}$ supply in tropical and subtropical forests of China, which often suffer from $\mathrm{P}$ deficiency. Some studies have reported changes in soil acid phosphatase activity in response to a more pronounced drought (Sardans and Penuelas, 2005). However, to the best of our knowledge, such investigations of acid phosphatase activity have not been conducted in any of the tropical and subtropical forests in China.

The Dinghushan Biosphere Reserve (DBR) possesses some typical forests in southern China, consisting of a pioneer community (Masson pine forest, MPF), a transition community (coniferous and broad-leaved mixed forest, MF) and a climax community (monsoon evergreen broad-leaved forest, MEBF). These forests provide an excellent opportunity to study $\mathrm{P}$ cycling along with a natural forest successional gradient. Previous studies have suggested that soil available $P$ is relatively low in this region (Huang et al., 2009) and $\mathrm{P}$ is possibly one of the factors limiting the plant productivity in MEBF of the DBR (Mo et al., 2000). In this case, we try to examine different responses of soil acid phosphatase activity to precipitation in the three forests with different $P$ requirements. A field experiment of precipitation treatments, including no precipitation (NP), natural precipitation (control) and doubled precipitation (DP) in the three forests, was conducted to test the hypotheses: (1) driven by seasonality of precipitation, soil acid phosphatase activity would be higher in the wet season than in the dry season; (2) soil acid phosphatase activity would be greater in the later stages of forest succession and exhibit different responses to precipitation treatments depending on forest types; (3) precipitation treatments would exert different effects on soil acid phosphatase activity between the dry and wet seasons.

\section{Materials and methods}

\subsection{Site description}

This study was carried out in the DBR $\left(23^{\circ} 09^{\prime} 21^{\prime \prime} \mathrm{N}-\right.$ $23^{\circ} 11^{\prime} 30^{\prime \prime} \mathrm{N}, 112^{\circ} 30^{\prime} 39^{\prime \prime} \mathrm{E}-112^{\circ} 33^{\prime} 41^{\prime \prime} \mathrm{E}$ ), located in the central part of Guangdong province, South China. DBR is the first natural reserve in China with an area of 1133 ha. The reserve is characterized by a typical subtropical monsoon humid climate with an annual average relative humidity of $80 \%$. The mean annual temperature is $21^{\circ} \mathrm{C}$, with a minimum monthly average temperature at $12.6^{\circ} \mathrm{C}$ in January and a maximum one at $28^{\circ} \mathrm{C}$ in July. The annual average precipitation of $1927 \mathrm{~mm}$ has a distinct seasonal pattern, with about $80 \%$ of it falling from April to September (wet-warm season) and $20 \%$ occurring from October to March (dry-cool season). The bedrock is sandstone and shale. Soils are classified in the ultisol group and udult subgroup according to USDA soil classification system (Buol et al., 2003).

In the DBR, key vegetation types consist of MPF, MF and MEBF, and they represent a sequence of natural successional stages, from pioneer community (MPF), transition community (MF) to regional climax vegetation (MEBF). MPF, belonging to the first stage of the successional processes, occurs in the periphery of the reserve at an elevation of about $200 \mathrm{~m}$. It was planted in the 1950s. The dominant species in MPF is Pinus massoniana Lamb. (Brown et al., 1995). The texture of top soil in MPF is medium gravel-medium loam, and the capacity of field moisture and wilting coefficient in the soil expressed as gravimetric water content are $26.0 \%$ and $10.9 \%$, respectively (Zhang and Zhuo, 1985). The MF is distributed between the core area and periphery of the reserve at an elevation of about $200-300 \mathrm{~m}$. It originated from MPF planted in the 1930s. Due to a gradual invasion of some pioneer broadleaf species through natural succession, the plant composition in MF had greatly changed. Dominant species in the canopy layer of MF are P. massoniana, Schima superba Gardn. et Champ, Castanopsis chinensis Hance, and Craibiodendron scleranthum var. kwangtungense (S. Y. Hu) Judd. If sufficient time was allowed, MF is believed to develop into MEBF (Wang and Ma, 1982). The texture of top soil in MF belongs to medium gravel-heavy loam with field capacity and wilting point at $25.3 \%$ and $8.2 \%$ gravimetric water content, respectively (Zhang and Zhuo, 1985). MEBF is distributed in the core area of the reserve at an elevation varying from 200 to $300 \mathrm{~m}$. It has been undisturbed for more than $400 \mathrm{yr}$ (G. Y. Zhou et al., 2006). Major species in MEBF include C. chinensis, Machilus chinensis (Champ. ex Benth.) Hemsl., S. superba, Cryptocarya chinensis (Hance) Hemsl., Syzygium rehderianum Merr. et Perry in the canopy and subcanopy layers. The texture of top soil in MEBF is light gravel-heavy loam. The water retention ability of top soil is the highest with the capacity of field moisture and wilting coefficient at $34.6 \%$ and $11.4 \%$ gravimetric water content, respectively (Zhang and Zhuo, 1985).

\subsection{Experiment design}

The precipitation experiment was started within the three forests in December 2006. Three precipitation treatments consisted of no precipitation (NP), natural precipitation (control) and doubled precipitation (DP). Each treatment was replicated three times. In each forest, we selected the plots with similar slope aspect, slope degree, slope position and community structure in order to minimize the heterogeneity 
among them. Each plot had a dimension of $3 \times 3 \mathrm{~m}$, and the distance between plots was more than $1 \mathrm{~m}$. Precipitation was intercepted in the NP plots using polyvinyl chloride (PVC) sheer roof and was redistributed to the DP plots (Borken et al., 2006; X. H. Zhou et al., 2006). The control plot receiving natural precipitation was built beside these treatment plots. Around each NP plot, the thick PVC plates were inserted into grounds at $15 \mathrm{~cm}$ deep to prevent surface runoff and lateral movement of water from the surrounding soil. The litter falling on precipitation interception roofs of NP plots was removed manually and periodically sprinkled on soils below the plates (Chen et al., 2010). Soil moisture of the top $5 \mathrm{~cm}$ soil layer, determined as volumetric soil water content $(\%$, $\mathrm{cm}^{3} \mathrm{~cm}^{-3}$ ), was measured on five random locations twice a month throughout the experiment within a plot using a MPKit (ICT, Australia, see http://www.ictinternational.com.au/ soils.htm), which consists of three amplitude domain reflectometry (ADR) moisture probes (MP406) and a data logger (MPM160 meter) (Tang et al., 2006).

\subsection{Soil sampling}

We conducted soil sampling in February (the dry season) and June (the wet season) 2009. For each plot, we collected soil samples from $0-20 \mathrm{~cm}$ mineral soils after removal of the litter layer. Six soil cores $(2.5 \mathrm{~cm}$ in diameter) were randomly taken and evenly combined to one sample in each plot. Soil samples were put in sealed plastic bags and immediately taken to the laboratory. Each sample was passed through a $2 \mathrm{~mm}$ sieve after removing roots, stones and other impurities. We divided each sample into two aliquots. One aliquot was air dried for analysis of related soil chemical properties. The other one was kept without drying at $4{ }^{\circ} \mathrm{C}$ until analysis of acid phosphatase activity was conducted. The measurement procedures of soil acid phosphatase activity were completed within 28 days.

\subsection{Soil chemical properties and acid phosphatase activity measurements}

Gravimetric soil moisture was determined from mass loss after drying for $24 \mathrm{~h}$ at $105^{\circ} \mathrm{C}$. Soil $\mathrm{pH}$ was measured in a deionized water suspension using glass electrodes at a ratio of $25 \mathrm{ml}$ water to $10 \mathrm{~g}$ soil (Liu et al., 1996). Total carbon (C) was determined by dichromate oxidation before titration with a Fe ${ }^{2+}$ solution (Liu et al., 1996). Total $\mathrm{N}$ was measured by semimicro-Kjeldahl digestion followed by steam distillation and final titration of ammonium (Liu et al., 1996). Total $\mathrm{P}$ was determined colorimetrically after digestion (Liu et al., 1996). Available $P$ was extracted with a solution containing $0.03 \mathrm{M} \mathrm{NH}_{4} \mathrm{~F}$ and $0.025 \mathrm{M} \mathrm{HCl}$ (Liu et al., 1996).

Soil acid phosphatase activity was measured using paranitrophenyl phosphate ( $p$-NPP) as an orthophosphate monoester analogue substrate. We used the method of Schneider et al. (2000) based on the original one of Tabatabai and
Bremner (1969). We took $1 \mathrm{~g}$ of fresh soil $(<2 \mathrm{~mm})$ in a $100 \mathrm{ml}$ Erlenmeyer flask, added $4 \mathrm{ml}$ of modified universal buffer (pH 6.5) and $1 \mathrm{ml}$ of $100 \mathrm{mM} p$-NPP substrate dissolved in the buffer, and swirled the flask slightly for a few seconds to mix the contents. The flask was then sealed and incubated at $30^{\circ} \mathrm{C}$ for $30 \mathrm{~min}$. After incubation, we immediately placed the flask on ice and then added $1 \mathrm{ml}$ of $2 \mathrm{M} \mathrm{CaCl}_{2}$ and $4 \mathrm{ml}$ of $0.2 \mathrm{M} \mathrm{NaOH}$ to terminate the reaction and extract the para-nitrophenol ( $p$-NP) formed. The sample was diluted with $90 \mathrm{ml}$ of deionized water and then filtered through Whatman-42 filter paper. Absorbance of released $p$ $\mathrm{NP}$ was determined spectrophotometrically at $400 \mathrm{~nm}$. Four replicates including one blank were used for each soil sample. For the blank, $p$-NPP was added after (instead of before) the incubation. The acid phosphatase activity was expressed as $\mu \mathrm{mol} p$-NP per gram dry soil and incubation time ( $\mu \mathrm{mol} p$ $\mathrm{NP} \mathrm{g}^{-1} \mathrm{~h}^{-1}$ ).

\subsection{Statistical analysis}

Data analyses were carried out with SPSS 11.5 for windows. We applied the t-test for independent samples to analyze differences between the dry and wet seasons for soil moisture, soil chemical properties and soil acid phosphatase activity in the three forests. A two factorial ANOVA was used to study the effects of season, forest type and their interaction on the variables. We used ANOVA followed by Tukey multiple comparison test to study: (1) the differences among the controls of three forests for soil moisture, soil chemical properties and soil acid phosphatase activity; (2) the effects of precipitation intensity on soil moisture, soil chemical properties and soil acid phosphatase activity among the treatments separately for each season and forest. In addition, Pearson correlation coefficients were calculated to show the relationships between soil chemical properties and acid phosphatase activity. For all statistical tests, we chose the probability level to reject the null hypothesis to be inferior or equal to 0.05 unless otherwise stated.

\section{Results}

\subsection{Soil moisture}

The mean soil moisture in the dry season (from October to March of the next year) was relatively lower than in the wet season (from April to September) (Fig. 1), but the difference in soil moisture between the two seasons was significant only in MPF $(P<0.01)$. In controls, the values of annual mean soil moisture were $19.2 \%$ for MPF, $27.2 \%$ for $\mathrm{MF}$ and $27.5 \%$ for MEBF, respectively. MF and MEBF showed significantly greater annual mean soil moisture than MPF $(P<0.01)$, but there was no significant difference between MF and MEBF. In all the three forests, NP treatments significantly decreased soil moisture $(P<0.01)$, while DP treatments had no significant effects on it except for MPF in 


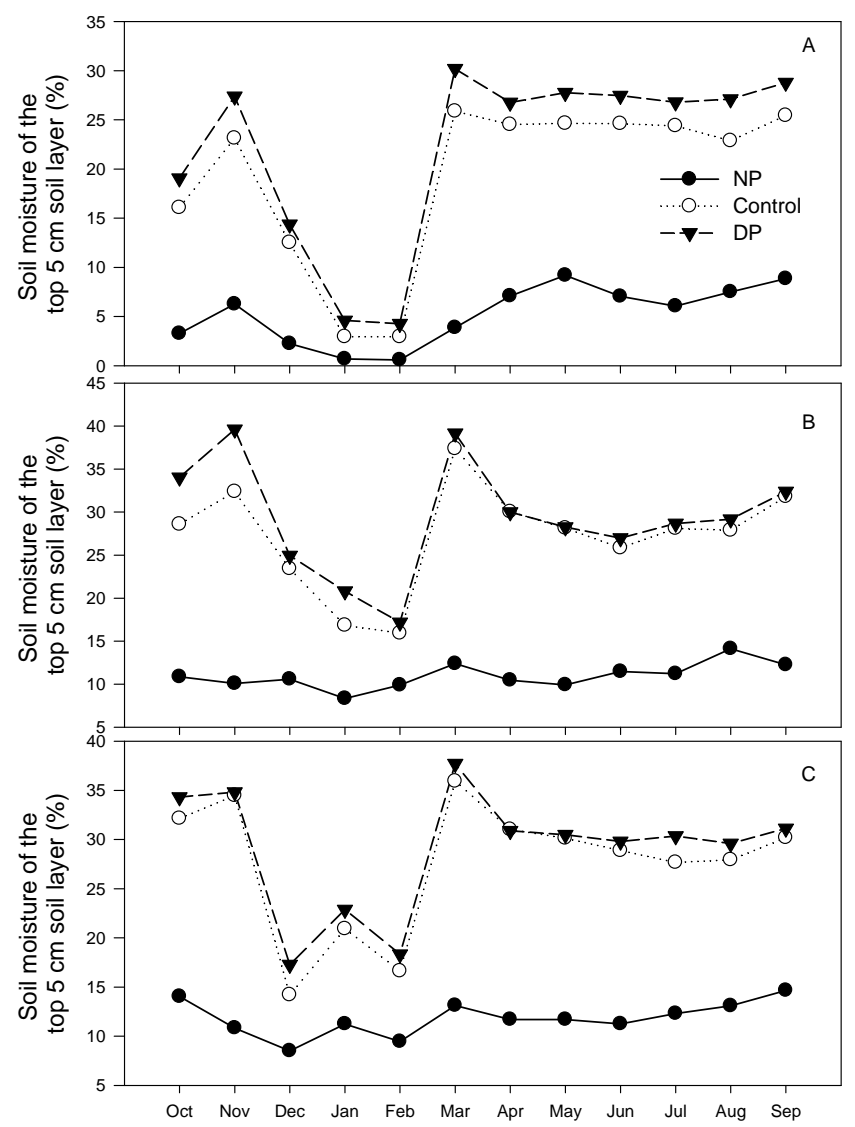

Fig. 1. Seasonal dynamics of soil moisture of the top $5 \mathrm{~cm}$ soil layer under different precipitation treatments from October 2008 to September 2009 in Masson pine forest (A), coniferous and broadleaved mixed forest (B) and monsoon evergreen broad-leaved forest (C) of Dinghushan Biosphere Reserve. NP, no precipitation; Control, natural precipitation; DP, double precipitation.

the wet season, which showed significantly greater soil moisture in DP treatment than in control $(P<0.01)$.

\subsection{Soil chemical properties}

The wet season exhibited significantly higher soil $\mathrm{pH}$ but lower available $\mathrm{P}(P<0.01)$ than the dry season, while there were no significant differences in total $\mathrm{C}$, total $\mathrm{N}$ and total $\mathrm{P}$ between the two seasons (Tables 1 and 2). Soil chemical properties significantly differed between forest types (Table 1).

For the dry season, significantly higher soil $\mathrm{pH}$ but lower total $\mathrm{C}$ were detected in the control of MPF than in those of MEBF $(P<0.01$ for soil $\mathrm{pH})$ and MF $(P<0.01$ for both). Total $\mathrm{P}$ and available $\mathrm{P}$ were significantly higher in MEBF than those in MF $(P<0.01$ for both). There were no significant differences in total $\mathrm{N}$ among the three forests. Precipitation treatments did not significantly affect related soil chemical properties except for available $\mathrm{P}$ in MEBF, which was
Table 1. Effects of season, forest type and their interactions on soil chemical properties. Numbers are $F$-values. Stars indicate the level of significance at $P<0.05$ (no star, not significant at $P>0.05$ ).

\begin{tabular}{lccccc}
\hline & $\mathrm{pH}$ & $\begin{array}{c}\text { Total } \\
\mathrm{C}\end{array}$ & $\begin{array}{c}\text { Total } \\
\mathrm{N}\end{array}$ & $\begin{array}{c}\text { Total } \\
\mathrm{P}\end{array}$ & $\begin{array}{c}\text { Available } \\
\mathrm{P}\end{array}$ \\
\hline Season & $14.61^{*}$ & 0.01 & 3.19 & 3.31 & $30.44^{*}$ \\
Forest type & $65.28^{*}$ & $26.29^{*}$ & $50.28^{*}$ & $109.54^{*}$ & $23.74^{*}$ \\
Season* Forest type & 0.48 & 1.88 & 1.36 & 2.25 & $15.88^{*}$ \\
\hline
\end{tabular}

significantly reduced by DP treatment in comparison with NP treatment (Table 2).

For the wet season, MPF exhibited significantly higher soil $\mathrm{pH}$ and lower total $\mathrm{P}(P<0.01)$ than MEBF in the controls. Total $\mathrm{C}$ and total $\mathrm{N}$ in the controls of MEBF and MF were significantly higher than those of MPF $(P<0.01$ for all), while the concentrations of available $P$ in both MEBF and MF were significantly lower than that in MPF $(P<0.01$ for both). The differences of the soil chemical properties between MEBF and MF did not arrive at a significant level. Soil $\mathrm{pH}$ exhibited an increasing trend with increasing precipitation treatments in three forests, but it was only significantly lowered by NP treatment when compared with DP treatment and control $(P<0.01$ for both) in MEBF. The other chemical properties were not greatly affected by precipitation treatments.

\subsection{Soil acid phosphatase activity}

In all cases, the wet season showed significantly higher soil acid phosphatase activities than the dry season $(P<0.01)$. On average, the value of soil acid phosphatase activity in the wet season was 1.33 times greater than in the dry season. In the two seasons, the controls of MEBF and MF exhibited significantly higher soil acid phosphatase activities than that of MPF ( $P<0.01$ for both), and the difference between MEBF and MF was not significant. The mean values of soil acid phosphatase activity in the two seasons were $4.89 \mu \mathrm{mol} p$ $\mathrm{NP} \mathrm{g}^{-1} \mathrm{~h}^{-1}$ for MPF, $12.41 \mu \mathrm{mol} p$-NP g ${ }^{-1} \mathrm{~h}^{-1}$ for MF and $12.29 \mu \mathrm{mol} p$-NP g ${ }^{-1} \mathrm{~h}^{-1}$ for MEBF, respectively.

The responses of soil acid phosphatase activity to precipitation varied with seasons and forests (Fig. 2). In the dry season, increasing precipitation treatments exerted positive impacts on soil acid phosphatase activities in the three forests (Fig. 2a). For MPF, DP treatment significantly increased soil acid phosphatase activity when compared with NP treatment and control ( $P<0.01$ for both), and the difference between NP treatment and control was not significant. For MF, soil acid phosphatase activity in NP treatment was around $21 \%$ and $23 \%$ lower than control and DP treatment, respectively. As for MEBF, although the differences in soil acid phosphatase activity among treatments 
Table 2. Soil chemical properties and their responses to precipitation treatments in $0-20 \mathrm{~cm}$ mineral soils of three forests in the dry and wet seasons at Dinghushan Biosphere Reserve. Mean values within a column in each forest for each season followed by different lowercase letters have significant treatment differences at $P<0.05$. MPF, Masson pine forest; MF, coniferous and broad-leaved mixed forest; MEBF, monsoon evergreen broad-leaved forest. NP, no precipitation; Control, natural precipitation; DP, double precipitation.

\begin{tabular}{|c|c|c|c|c|c|c|c|}
\hline \multirow[t]{2}{*}{ Time } & \multirow[t]{2}{*}{ Forest } & \multirow[t]{2}{*}{ Treatment } & \multirow[t]{2}{*}{$\mathrm{pH}$} & Total C & Total N & Total P & \multirow{2}{*}{$\begin{array}{l}\text { Available P } \\
\mathrm{mg} \mathrm{kg}^{-1}\end{array}$} \\
\hline & & & & \multicolumn{3}{|c|}{$\mathrm{mg} \mathrm{g}^{-1}$} & \\
\hline \multirow[t]{9}{*}{ Dry season } & MPF & NP & 4.06 & 15.49 & 1.16 & 0.16 & 1.61 \\
\hline & & Control & 4.09 & 13.80 & 1.25 & 0.14 & 1.05 \\
\hline & & DP & 4.13 & 12.17 & 0.88 & 0.15 & 1.21 \\
\hline & MF & NP & 3.82 & 24.10 & 1.51 & 0.16 & 0.72 \\
\hline & & Control & 3.81 & 29.69 & 1.81 & 0.16 & 0.65 \\
\hline & & DP & 3.93 & 23.95 & 1.52 & 0.16 & 0.74 \\
\hline & MEBF & $\mathrm{NP}$ & 3.67 & 27.32 & 1.76 & 0.22 & $2.62 \mathrm{a}$ \\
\hline & & Control & 3.81 & 23.90 & 1.49 & 0.21 & $1.47 \mathrm{ab}$ \\
\hline & & DP & 3.77 & 27.38 & 1.67 & 0.21 & $1.44 \mathrm{~b}$ \\
\hline \multirow[t]{9}{*}{ Wet season } & MPF & NP & 4.14 & 21.32 & 1.10 & 0.16 & 1.45 \\
\hline & & Control & 4.15 & 15.24 & 1.05 & 0.15 & 1.39 \\
\hline & & DP & 4.23 & 15.11 & 1.07 & 0.15 & 1.27 \\
\hline & MF & NP & 3.95 & 22.84 & 1.64 & 0.17 & 0.22 \\
\hline & & Control & 3.99 & 27.04 & 1.88 & 0.20 & 0.30 \\
\hline & & DP & 4.01 & 26.14 & 1.74 & 0.17 & 0.22 \\
\hline & MEBF & NP & $3.67 \mathrm{~b}$ & 24.51 & 1.94 & 0.21 & 0.74 \\
\hline & & Control & $3.90 \mathrm{a}$ & 23.75 & 1.83 & 0.23 & 0.43 \\
\hline & & $\mathrm{DP}$ & $3.92 \mathrm{a}$ & 22.76 & 1.77 & 0.22 & 0.21 \\
\hline
\end{tabular}

were not significant, it showed a positive response to increasing precipitation. The values were in this order: $8.70 \mu \mathrm{mol} p$ $\mathrm{NP} \mathrm{g}^{-1} \mathrm{~h}^{-1}$ for NP treatment $<9.77 \mu \mathrm{mol} p-\mathrm{NP} \mathrm{g}^{-1} \mathrm{~h}^{-1}$ for control $<10.54 \mu \mathrm{mol} p-\mathrm{NP} \mathrm{g}^{-1} \mathrm{~h}^{-1}$ for DP treatment. In the wet season, soil acid phosphatase activities were all significantly lowered by NP treatments in the three forests $(P<$ 0.01 for all) (Fig. 2b). However, they were not stimulated by DP treatments in both MPF and MF, and it was even significantly depressed by DP treatment in MEBF. Among the three forests, the responses of soil acid phosphatase activity to precipitation treatments were the most pronounced in MEBF. The differences among the three treatments in MEBF all came up to significant levels.

\subsection{Relationships between soil chemical properties and soil acid phosphatase activity}

Soil acid phosphatase activity had a significantly negative correlation with soil $\mathrm{pH}$ and available $\mathrm{P}$. The relationships of soil acid phosphatase activity to total $\mathrm{C}$, total $\mathrm{N}$ and total $\mathrm{P}$ were all significantly positive (Table 3 ).

\section{Discussion}

The acid phosphatase activity in soils of the three forests was assayed under the optimum acidity condition with $\mathrm{pH}$ equal to 6.5 (Tabatabai and Bremner, 1969; Tabatabai, 1994; Schneider et al., 2000). Although enzyme activity determined at the optimum $\mathrm{pH}$ is usually higher than that under soil pH (Turner et al., 2002), the optimum condition can provide a consistent background for comparison. In our study, it is important to detect $\mathrm{P}$ demand and potential mineralization of soil organic $\mathrm{P}$ in response to precipitation across the three forests. The same acidity condition can minimize the influence of soil $\mathrm{pH}$ on acid phosphatase activities across the three forests, and thus, the measured results better reflect the differences in P demand.

\subsection{Soil acid phosphatase activity in the dry and wet seasons}

Phosphatases are inducible enzymes regulated by endproduct inhibition. Plant roots and microbes will increase the excretion of phosphatases into soils when available $\mathrm{P}$ does not meet their demands (Goldstein et al., 1988). This mechanism was clearly evident from the significantly negative correlation between acid phosphatase activity and available $\mathrm{P}$ in 


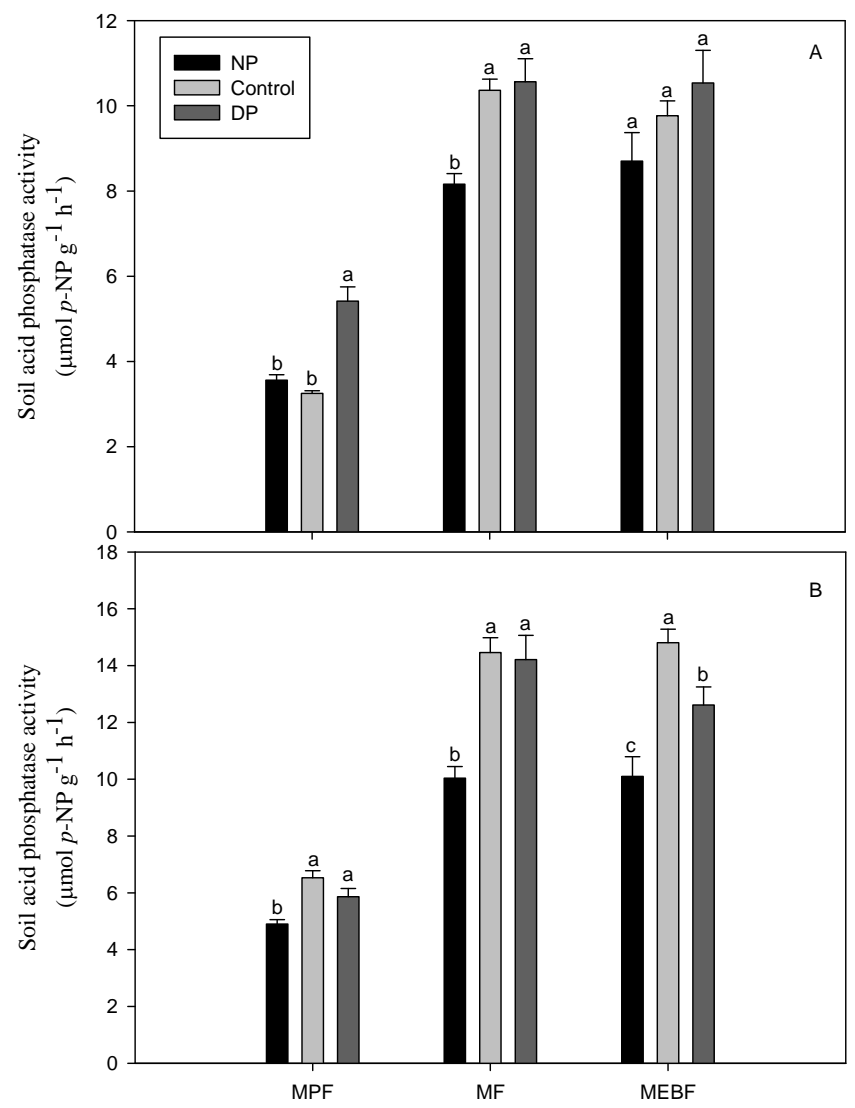

Fig. 2. Soil acid phosphatase activity in the dry (A) and wet (B) seasons under different precipitation treatments in $0-20 \mathrm{~cm}$ mineral soils of three forests at Dinghushan Biosphere Reserve. Error bars represent standard errors. Different lowercase letters denote significant differences between treatments at $P<0.05$ in the same forest. MPF, Masson pine forest; MF, coniferous and broad-leaved mixed forest; MEBF, monsoon evergreen broad-leaved forest. NP, no precipitation; Control, natural precipitation; DP, double precipitation.

our results (Table 3). It is expected that soil acid phosphatase activity would be clearly greater in the wet season than in the dry season in our experiment, a seasonal pattern observed previously by Grierson and Adams (2000). Actually, in the wet season, plants grow fast, and microbial biomass is always high (Table 4). This increasing enzyme activity would respond to meet the increasing $\mathrm{P}$ demand by plant and microbe growth in the wet season. Since heavy rain in the wet season often leads to nutrient loss, low available P detected in the wet season (Tables 1 and 2) further intensifies the competition for $\mathrm{P}$ in ecosystems in the growing season. On the contrary, dry season is the least biologically active period. Soil available $\mathrm{P}$ was relatively high (Tables 1 and 2 ) to meet the biological demands because of the accumulation of nutrients released from litter decomposition and low soil nutrient diffusion (Xia et al., 1997).
Table 3. Pearson correlation coefficients between soil acid phosphatase activity and soil chemical properties at Dinghushan Biosphere Reserve.

\begin{tabular}{lccccc}
\hline & $\mathrm{pH}$ & $\begin{array}{c}\text { Total } \\
\mathrm{C}\end{array}$ & $\begin{array}{c}\text { Total } \\
\mathrm{N}\end{array}$ & $\begin{array}{c}\text { Total } \\
\mathrm{P}\end{array}$ & $\begin{array}{c}\text { Available } \\
\mathrm{P}\end{array}$ \\
\hline $\begin{array}{l}\text { Soil acid phosphatase } \\
\text { activity }\end{array}$ & -0.463 & 0.650 & 0.743 & 0.623 & -0.460 \\
\begin{tabular}{l} 
Significant level \\
\hline
\end{tabular} & $<0.00$ & $<0.00$ & $<0.00$ & $<0.00$ & $<0.00$ \\
\hline
\end{tabular}

Table 4. Mean soil microbial biomass $C$ of the top $20 \mathrm{~cm}$ soil layer under different precipitation treatments in 2008 in three forests of Dinghushan Biosphere Reserve. Mean values within a column in each season followed by different lowercase letters have significant treatment differences at $P<0.05$. MPF, Masson pine forest; MF, coniferous and broad-leaved mixed forest; MEBF, monsoon evergreen broad-leaved forest. NP, no precipitation; Control, natural precipitation; DP, double precipitation.

\begin{tabular}{llccc}
\hline \multirow{2}{*}{ Time } & Treatment & MPF & MF & MEBF \\
\cline { 3 - 5 } & & \multicolumn{3}{c}{$\mathrm{mg} \mathrm{kg}^{-1}$} \\
\hline Dry season* & NP & $156 \mathrm{c}$ & $175 \mathrm{~b}$ & $311 \mathrm{~b}$ \\
& Control & $279 \mathrm{~b}$ & $384 \mathrm{a}$ & $451 \mathrm{a}$ \\
& DP & $368 \mathrm{a}$ & $411 \mathrm{a}$ & $456 \mathrm{a}$ \\
\hline Wet season* & NP & $287 \mathrm{~b}$ & $347 \mathrm{c}$ & $483 \mathrm{~b}$ \\
& Control & $442 \mathrm{a}$ & $527 \mathrm{~b}$ & $711 \mathrm{a}$ \\
& DP & $542 \mathrm{a}$ & $697 \mathrm{a}$ & $705 \mathrm{a}$ \\
\hline
\end{tabular}

* Significant difference between the dry and wet seasons at $P<0.05$. Data in the table cited from Q. Deng et al. (unpublished data, 2011).

\subsection{Effects of forest succession on soil acid phosphatase activity in the controls}

Results showed that MF and MEBF exhibited higher soil acid phosphatase activities than MPF. Although available P could exert a negative feedback on phosphatase activity, the pattern in acid phosphatase activity across the three forests was not explained by the variability in available $\mathrm{P}$ in the three forests. An alternative explanation could be that soil nutrient status and vegetation conditions in the three forests influence soil acid phosphatase activity (Harrison, 1983; Ushio et al., 2010).

Our results also showed that soil chemical properties had close relationships with soil acid phosphatase activity (Table 3). This was also partly confirmed by other studies (Schneider et al., 2000; Turner and Haygarth, 2005; C. R. Chen et al., 2003, 2008), indicating that the better soil nutrient condition, the higher soil acid phosphatase activity would be. In the DBR, soil nutrient condition in MF was comparable with that in MEBF despite their different successional stages, but they were both superior to 
that in MPF (Table 2). Soil microbial biomass was elevated in the later stages of forest succession (Table 4). This necessarily resulted in high soil acid phosphatase activities in MF and MEBF as this enzyme partly originates from microbes. Moreover, with progressive forest succession $(\mathrm{MPF} \rightarrow \mathrm{MF} \rightarrow \mathrm{MEBF}$ ), plant community developed from almost monospecific with only occasional broad-leaved tree species to rich and diversiform species. The biomass, litterfall production (Table 5) and litter decomposition rate (Mo et al., 2006), which were very important in balancing loss and removal of $\mathrm{P}$ from mineral soils by plant uptake and microbial activity (C. R. Chen et al., 2000, 2003), exhibited an increasing tendency with progressive successional stages. Thus, acid phosphatase activity was enhanced with forest succession.

As soil acid phosphatase activity is a prevailing indicator of the degree in P limitation (Turner et al., 2002), our result might reflect an enhanced biological P limitation in the later successional forests. This was partly supported by Mo et al. (2000), suggesting that $\mathrm{P}$ was possibly one of the factors limiting the plant productivity in the mature forest of the DBR.

\subsection{Effects of precipitation treatments on soil acid phosphatase activity}

In the dry season, increasing precipitation treatments had positive effects on soil acid phosphatase activity in the three forests, although the extent of effects differed between forest types. Zhou and Yan (2001) studying in this area stated that owing to moderate solar radiation input in dry season, plant growth potential still kept high and demanded for moderate water, but less rainfall in the season could not meet the need. Increased precipitation input has a direct benefit to plant growth, and correspondingly, $\mathrm{P}$ demand will be enhanced. We observed that precipitation treatments did not affect soil total C, total $\mathrm{N}$ and total $\mathrm{P}$ (Table 2). The results indicate that changes in soil acid phosphatase activity might be more dependent on soil moisture rather than a consequence of changes in the substrate.

However, the amount of water requirement varied with forest types. In MPF, our results showed that soil acid phosphatase activity was only greatly enhanced by DP treatment, demonstrating that water was a key limiting factor in controlling the $\mathrm{P}$ cycling due to its own quite low soil moisture (Fig. 1). As a transition community, MF had higher acid phosphatase activities in control and DP treatment than in NP treatment. This indicates that soil water is not a limited factor to $\mathrm{P}$ mineralization, and that increased water in MF is not as important as that in MPF. As a regional climax community, MEBF had a wholesome self-regulating mechanism and a high capability of resisting outside interference. Thus, in the dry season, precipitation treatments did not markedly influence soil acid phosphatase activity. In this case, the significantly low available P in DP treatment (Table 2), possibly
Table 5. Relevant factors related to soil acid phosphatase activity in three forests of Dinghushan Biosphere Reserve. MPF, Masson pine forest; MF, coniferous and broad-leaved mixed forest; MEBF, monsoon evergreen broad-leaved forest.

\begin{tabular}{lccc}
\hline Forest & MPF & MF & MEBF \\
\hline Biomass $\left(\mathrm{Mg} \mathrm{Cha}^{-1}\right)$ & 40.6 & 116.2 & 147.8 \\
Litterfall production $\left(\mathrm{g} \mathrm{m}^{-2} \mathrm{yr}^{-1}\right)$ & 356 & 861 & 849 \\
Fine root biomass $\left(\mathrm{Mg} \mathrm{Cha}^{-1}\right)^{*}$ & 1.9 & 2.8 & 4.9 \\
Soil available N $\left(\mathrm{mg} \mathrm{kg}^{-1}\right)$ & 6.24 & 6.22 & 14.77 \\
\hline
\end{tabular}

* Fine root biomass refers to root biomass in 0-20 cm depth of soils. Data in table cited from Fang et al. (2004), Peng and Zhang (1994), Tang et al. (2006), Wen et al. (1998), and Zhou et al. (2007).

induced by $\mathrm{P}$ loss from leaching, was not accompanied by sufficiently high acid phosphatase activity. This would further intensify competition for $\mathrm{P}$ in the mature forest.

In the wet season, soil acid phosphatase activities in three forests exhibited different patterns in responses to precipitation treatments. That NP treatment had a clearly negative effect on soil acid phosphatase activity was consistent with the results reported in other literatures, representing that phosphatase activity was well correlated with soil water availability (Krämer and Green, 2000; Sardans and Penuelas, 2005, Sardans et al., 2008). Q. Deng et al. (unpublished data, 2011) found that soil microbial biomass was significantly depressed by NP treatments in the three forests (Table 4). This could be responsible for the decrease in acid phosphatase activity. In MEBF, the increasing acidity of soil accompanied by the prolonged drought condition (Table 2) might be another mechanism involved in the reduction of soil acid phosphatase activity. There is a considerable risk for aluminum toxicity in a relatively low soil $\mathrm{pH}$, which would inhibit plant root growth and nutrient absorption (Liu, 2000). Thus, these factors would decrease acid phosphatase activity as it is closely related to microbe and root growth (Tarafdar and Claassen, 1988). The decrease in soil acid phosphatase activity produced by drought would result in a reduction of $\mathrm{P}$ availability to plants, and further aggravate the stress of competition for $\mathrm{P}$ in this region in the long time.

Nevertheless, in the wet season, no positive effects and even some negative effects of DP treatments on soil acid phosphatase activity were detected in the three forests. Water brought by natural rainfall is sufficient for plant growths because of large rainfall occurring in the wet season (Zhou and Yan, 2001). More water has no competitive advantage under enhanced $\mathrm{P}$ demands in the growing season. As soil moisture was already high in MEBF (Fig. 2), more water input would impede the diffusion of oxygen in the soils (Davidson et al., 1998). In an anoxic condition, plant root growth and microbial activity would be restrained (Q. S. Chen et al., 2003), which could be responsible for the significantly lower acid phosphatase activity in DP treatment in MEBF. 
The implication of the decreased acid phosphatase activity would be a decline in the potential mineralization of organic $\mathrm{P}$ in MEBF. Moreover, from our observation, the $\mathrm{N}$ input with the rainfall was about $35 \mathrm{~kg} \mathrm{Nha}^{-1} \mathrm{yr}^{-1}$ during the past twenty years (Huang et al., 2011b). Doubled rainfall brought about more available $\mathrm{N}$ input into MEBF, which already had great soil available $\mathrm{N}$ (Table 5). In this case, more available $\mathrm{P}$ would be required to match the increase in $\mathrm{N}$ (Huang et al., 2011a). Thus, higher $\mathrm{N}$ availability and lower acid phosphatase activity induced by DP treatment would be involved in more intensified $\mathrm{P}$ deficiency in the mature forest.

\section{Conclusions}

Driven by the seasonality of precipitation, soil acid phosphatase activities presented an obvious seasonal pattern, with high values in the wet season and low ones in the dry season, which corresponded to the most biological activity and lower soil available $\mathrm{P}$ in the growing season. Forest succession and soil acid phosphatase activity were positively related, with the smallest values in MPF, followed by MF and MEBF. This suggests that the requirements for $\mathrm{P}$ by ecosystems might be enhanced in the later stages of forest succession. Our results also show that a reasonable distribution of water plays a critical role in controlling the rate of $\mathrm{P}$ cycling in subtropical forest soils. In the dry season, there was a trend toward increasing soil acid phosphatase activity with elevating precipitation treatments in the three forests, while the extent of increase differed between forest types. In the wet season, drought caused decreases in soil acid phosphatase activities within the three forests. However, DP treatments exerted little effects on soil acid phosphatase activity except for that in MEBF, showing clearly negative effects on it. The negative effects of precipitation on soil acid phosphatase activity suggest that drought throughout the year would be adverse to organic $\mathrm{P}$ turnover in the three forests, while more rainfall in the wet season would depress organic $\mathrm{P}$ turnover in the mature forest.

Acknowledgements. The study was supported by projects of National Natural Science Foundation of China (Grant No. 30725006 and 31070439), Guangdong Provincial Natural Science Foundation of China (Grant No. 8351065005000001) and Basic Research Program of China (Grant No. 2009CB421101). We thank Yin $\mathrm{Li}$, Haiqing $\mathrm{He}$, Yanhong $\mathrm{Li}$ and others for their help in the field sample collection and analysis.

Edited by: A. Neftel

\section{References}

Attiwill, P. M. and Adams, M. A.: Nutrient cycling in forest, New Phytol., 124, 561-582, 1993.

Borken, W., Savage, K., Davidson, E. A., and Trumbore, S. E.: Effects of experimental drought on soil respiration and radiocarbon efflux from a temperate forest soil, Glob. Change Biol., 12, 177193, 2006.

Brown, S., Lenart, M. T., Mo, J. M., and Kong, G. H.: Structure and organic matter dynamics of a human-impacted pine forest in a MAB reserve of subtropical China, Biotropica, 27, 276-289, 1995.

Buol, S. W., Southard, R. J., Graham, R. C., and McDaniel, P. A.: Soil genesis and classificantion, fifth edition, Iowa State Press, Iowa, USA, 339-347, 2003.

Chen, C. R., Condron, L. M., Davis, M. R., and Sherlock, R. R.: Effects of afforestation on phosphorus dynamics and biological properties in a New Zealand grassland soil, Plant Soil, 220, 151163, 2000.

Chen, C. R, Condron, L. M., Davis, M. R., and Sherlock, R. R.: Seasonal changes in soil phosphorus and associated microbial properties under adjacent grassland and forest in New Zealand, Forest Ecol. Manag., 177, 539-557, 2003.

Chen, C. R., Condron, L. M., and Xu, Z. H.: Impacts of grassland afforestation with coniferous trees on soil phosphorus dynamics and associated microbial process: A review, Forest Ecol. Manag., 255, 396-409, 2008.

Chen, Q. S., Li, L. H., Han, X. G., and Yan, Z. D.: Effects of water content on soil respiration and the mechanisms, Acta Ecologica Sinica, 23, 972-978, 2003 (in Chinese with English abstract).

Chen, X. M., Liu, J. X., Deng, Q., Chu, G. W., Zhou, G. Y., and Zhang, D. Q.: Effects of precipitation intensity on soil organic carbon fractions and their distribution under subtropical forests of South China, Chinese Journal of Applied Ecology, 21, 12051211, 2010 (in Chinese with English abstract).

Clarholm, M.: Microbial biomass P, labile P, and acid phosphatase activity in the humus layer of a spruce forest, after repeated additions of fertilizers, Biol. Fert. Soils, 16, 287-292, 1993.

Davidson, E. A., Belk, E., and Boone, R. D.: Soil water content and temperature as independent or confounded factors controlling soil respiration in a temperate mixed hardwood forest, Glob. Change Biol., 4, 217-227, 1998.

Dick, W. A. and Tabatabai, M. A.: Soil microbial ecology: Application in agricultural and environmental management, in: Significance and potential uses of soil enzymes, edited by: Metting, F. B., Marcel Dekker, New York, USA, 95-125, 1993.

Fang, Y. T., Mo, J. M., Zhou, G. Y., Gundersen, P., Li, D. J., and Jiang, Y. Q.: The short-term responses of soil available nitrogen of Dinghushan forests to simulated $\mathrm{N}$ deposition in subtropical China, Acta Ecologica Sinica, 24, 2353-2359, 2004 (in Chinese with English abstract).

Garcia, C., Hernandez, T., Roldan, A., and Martin, A.: Effect of plant cover decline on chemical and microbiological parameters under Mediterranean climate, Soil Biol. Biochem., 34, 635-642, 2002.

Goldstein, A. H., Baertlein, D. A., and McDaniel, R. G.: Phosphate starvation inducible metabolism in Lycopersicon esculentum 1. Excretion of acid phosphatase by tomato plants and suspension culture cells, Plant Physiol., 87, 711-720, 1988.

Gress, S. E., Nichols, T. D., Northcraft, C. C., and Peterjohn, W. T.: Nutrient limitation in soils exhibiting differing nitrogen availablities: What lies beyond nitrogen saturation, Ecology, 88, 119130, 2007.

Grierson, P. F. and Adams, M. A.: Plant species affect acid phosphatase, ergosterol and microbial $\mathrm{P}$ in a Jarrah (Eucalyptus 
marginata Donn ex Sm.) forest in south-western Australia, Soil Biol. Biochem., 32, 1817-1827, 2000.

Harrison, A. F.: Relationship between intensity of phosphatase activity and physicochemical properties in woodland soils, Soil Biol. Biochem., 15, 93-99, 1983.

Houghton, J. T., Ding, Y., Griggs, D. J., Noguer, M., van der Linden, P. J., Dai, X., Maskell, K., and Johnson, C. A.: Climate Change 2001: the scientific basis, Contribution of working Group I to the third assessment report of the intergovernmental panel on climate change, Cambridge University Press, Cambridge, UK, 142-145, 2001.

Huang, W. J., Liu, J. X., Tang, X. L., Huang, Y. H., Liu, S. Z., Chu, G. W., and Zhou, G. Y.: Inorganic nitrogen and available phosphorus concentrations in the soils of five forests at Dinghushan, China, Chinese Journal of Applied and Environmental Biology, 15, 441-447, 2009 (in Chinese with English abstract).

Huang, W. J., Liu, J. X., Zhang, D. Q., Li, Y. L., Otieno, D., Xu, Z. H., Li, Y., Liu, S. Z., Chu, G. W., and Zhou, G. Y.: Responses of soil acid phosphomonoesterase activity to simulated nitrogen deposition in three forests of subtropical China, Pedosphere, in press, 2011a.

Huang, W. J., Zhou, G. Y., and Liu, J. X.: Nitrogen and phosphorus status and their influence on aboveground production under enriching nitrogen deposition in three successional forests, Acta Oecol., in press, 2011b.

Juma, N. G. and Tabatabai, M. A.: Comparison of kinetic and thermodynamic parameters of phosphomonoesterases of soils and of corn and soybean roots, Soil Biol. Biochem., 20, 533-539, 1988.

Krämer, S. and Green, D. M.: Acid and alkaline phosphatase dynamics and their relationship to soil microclimate in a semiarid woodland, Soil Biol. Biochem., 32, 179-188, 2000.

Leiros, M. C., Trasar-Cepeda, C., Garcia-Fernandez, F., and GilSotres, F.: Defining the validity of a biochemical index of soil quality, Biol. Fert. Soils, 30, 140-146, 1999.

Liu, G. S., Jiang, N. H., Zhang, L. D., and Liu, Z. L.: Soil physical and chemical analysis and description of soil profiles, Standards Press of China, Beijing, China, 121-265, 1996.

Liu, J. X.: Effect of aluminum toxicity on forests under acid deposition, Journal of Tropical and Subtropical Botany, 8, 269-274, 2000 (in Chinese with English abstract).

Luo, Y., Liu, S., Fu, S. L., Liu, J. S., Wang, G. Q., and Zhou, G. Y.: Trends of precipitation in Beijiang River basin, Guangdong province, China, Hydrol. Process., 22, 2377-2386, 2008.

Mo, J. M., Zhang, D. Q., Huang, Z. L., Yu, Q. F., and Kong, G. H.: Distribution pattern of nutrient elements in plants of Dinghushan lower subtropical evergreen broad-leaved forest, Journal of Tropical and Subtropical Botany, 8, 198-206, 2000 (in Chinese with English abstract).

Mo, J. M., Brown, S., Xue, J. H., Fang, Y. T., and Li, Z. A.: Response of litter decomposition to simulated $\mathrm{N}$ deposition in disturbed, rehabilitated and mature forests in subtropical China, Plant Soil, 282, 135-151, 2006.

Olander, L. P. and Vitousek, P. M.: Regulation of soil phosphatase and chitinase activity by $\mathrm{N}$ and $\mathrm{P}$ availability, Biogeochemistry, 49, 175-190, 2000.

Peng, S. L. and Zhang, Z. P.: Studies on the biomass, primary productivity and energy use efficiency of the mixed forest community in Mt. Dinghushan, Guangzhou, Acta Ecologica Sinica, 14, 300-305, 1994 (in Chinese with English abstract).
Raghothama, K. G.: Phosphate acquisition, Annu. Rev. Plant Phys., 50, 665-693, 1999.

Sardans, J. and Penuelas, J.: Drought decreases soil enzyme activity in a Mediterranean Quercus ilex L. forest, Soil Biol. Biochem., 37, 455-461, 2005.

Sardans, J., Penuelas, J., and Estiarte, M.: Seasonal patterns of rootsurface phosphatase activities in a Mediterranean shrubland. Responses to experimental warming and drought, Biol. Fert. Soils, 43, 779-786, 2007

Sardans, J., Penuelas, J., and Ogaya, R.: Experimental drought reduced acid and alkaline phosphatase activity and increased organic extractable P in soil in a Quercus ilex Mediterranean forest, Eur. J. Soil Biol., 44, 509-520, 2008.

Schneider, K., Turrion, M. B., and Gallardo, J. F.: Modified method for measuring acid phosphatase activities in forest soils with high organic matter content, Commun. Soil Sci. Plan., 31, 3077-3088, 2000.

Schneider, K., Turrion, M. B., Grierson, P. F., and Gallardo, J. F.: Phosphatase activity, microbial phosphorus, and fine root growth in forest soils in the Sierra de Gata, western central Spain, Biol. Fert. Soils, 34, 151-155, 2001.

Speir, T. W. and Ross, D. J.: Soil enzymes, in: Soil phosphatase and sulphatase, edited by: Burns, R. G., Academic Press, New York, USA, 198-250, 1978

Tabatabai, M. A.: Soil enzymes, in: Methods of Soil Analysis part 2, Microbiological and Biological Properties, edited by: Weaver, R. W., Angle, J. S., and Bottomley, P. S., Soil Science Society of America, Madison, WI, USA, 775-833, 1994.

Tabatabai, M. A. and Bremner, J. M.: Use of $p$-nitrophenyl phosphate for assay of soil phosphatase activity, Soil Biol. Biochem. 1, 301-307, 1969.

Tang, X. L., Liu, S. G., Zhou, G. Y., Zhang, D. Q., and Zhou, C. Y.: Soil-atmospheric exchange of $\mathrm{CO}_{2}, \mathrm{CH}_{4}$, and $\mathrm{N}_{2} \mathrm{O}$ in three subtropical forest ecosystems in southern China, Glob. Change Biol., 12, 546-560, 2006.

Tarafdar, J. C. and Claassen, N.: Organic phosphorus-compounds as a phosphorus source for higher-plants through the activity of phosphatases produced by plant-roots and microorganisms, Biol. Fert. Soils, 5, 308-312, 1988.

Turner, B. L. and Haygarth, P. M.: Phosphatase activity in temperate pasture soils: Potential regulation of labile organic phosphorus turnover by phosphodiesterase activity, Sci. Total Environ., 344, 27-36, 2005.

Turner, B. L., Baxter, R., and Whitton, B. A.: Seasonal phosphatase activity in three characteristic soils of the English uplands polluted by long-term atmospheric nitrogen deposition, Environ. Pollut., 120, 313-317, 2002.

Ushio, M., Kitayama, K., and Balser, T. C.: Tree species effects on soil enzyme activities through effects on soil physicochemical and microbial properties in a tropical montane forest on Mt. Kinabalu, Borneo, Pedobiologia, 53, 227-233, 2010.

Wang, B. S. and Ma, M. J.: The successions of the Forest community in Dinhushan, Tropical and Subtropical Forest Ecosystem Research, 1, 142-156, 1982 (in Chinese with English abstract).

Wen, D. Z., Zhang, D. Q., Wei, P., and Kong, G. H.: Vegetation biomass, coarse woody debris storage and litter dynamics of the community of Castanopsis chinensis, Cryptocarya concinna, Tropical and Subtropical Forest Ecosystem Research, 8, 32-39, 1998 (in Chinese with English abstract). 
Xia, H. P., Yu, Q. F., and Zhang, D. Q.: The soil acidity and nutrient contents, and their characteristics of seasonal dynamic changes under 3 different forests of Dinghushan Nature Reserve, Acta Ecological Sinica, 17, 645-653, 1997 (in Chinese with English abstract).

Zhai, P. M., Ren, F. M., and Zhang, Q.: Detection of trends in China's precipitation extremes, Acta Meteorol. Sin., 57, 208216, 1999.

Zhang, B. G. and Zhuo, M. N.: The physical properties of soil under different forest types in Ding Hu Shan Biosphere Reserve, Tropical and Subtropical Forest Ecosystem Research, 3, 1-10, 1985 (in Chinese with English abstract).

Zhou, G. Y. and Yan, J. H.: The influence of region atmospheric precipitation characteristics and its element inputs on the existence and development of Dinghushan forest ecosystems, Acta Ecologica Sinica, 21, 2002-2012, 2001 (in Chinese with English abstract).
Zhou, G. Y., Liu, S. G., Li, Z. A., Zhang, D. Q., Tang, X. L., and Zhou, C. Y.: Old-growth forests can accumulate carbon in soils, Science, 314, 1417, doi:10.1126/science.1130168, 2006.

Zhou, G. Y., Guan, L. L., Wei, X. H., Zhang, D. Q., Zhang, Q. M., Yan, J. H., Wen, D. Z., Liu, J. X., Liu, S. G., Huang, Z. L., Kong, G. H., Mo, J. M., and Yu, Q. F.: Litterfall production along successional and altitudinal gradients of subtropical monsoon evergreen broadleaved forests in Guangdong, China, Plant Ecol., 188, 77-89, 2007.

Zhou, X. H., Sherry, R. A., An, Y., Wallace, L. L., and Lou, Y. Q.: Main and interactive effects of warming, clipping, and doubled precipitation on soil $\mathrm{CO}_{2}$ efflux in a grassland ecosystem, Global Biogeochem. Cy., 20, GB1003, doi:10.1029/2005GB002526, 2006. 